\title{
IMPACT OF MANAGERIAL COMMUNICATION STYLES ON TEACHERS' JOB SATISFACTION IN PUBLIC SECTOR UNIVERSITIES
}

\section{Dr. Shazia Zamir ${ }^{1}$, Mahek Arshad ${ }^{2}$}

\begin{abstract}
Communication style refers to the preferred mode of linguistic and nonverbal behavior with respect to giving and receiving information in specific situations. Job satisfaction is a positive or negative feeling, and employees see how they feel about their work and the different aspects of their work. The present study aims to investigate the impact of managerial communication styles on teacher's job satisfaction. In this study descriptive research design was used. For collecting data survey design was used. Major objectives of the study were to find out the existing Managerial communication style in public sector universities and assess the impact of managerial communication style on teacher's job satisfaction in public sector universities. In order to select representative sample from the target population, 40 teachers and 10 heads were selected from one public sector university of Islamabad. Research findings revealed that that Dominant managerial communication style had the highest mean, whereas Friendly managerial communication style had the lowest mean score. Findings also suggest that a significant positive correlation exist between job satisfaction and communication styles which include friendly, attentive, relax, expressive, dramatic and open managerial styles.
\end{abstract}

Keywords: communication styles, teachers, job satisfaction, public university

\footnotetext{
${ }^{1}$ Assistant Professor, Department of Education, NUML Islamabad, szamir@numl.edu.pk

${ }^{2}$ Lecturer, Department of Education NUML Islamabad, mehakrshd@gmail.com
} 


\section{Introduction}

The part of communication in the organization cannot be undervalued. Communication can help individuals and groups coordinate their activities to achieve their goals, which are crucial in social decision-making and change management. Internal communication helps employees with important information regarding their work, organization, environment and each other (Zalabak, 2002). Communication can help motivate, build trust, build common identity and promote participation; it provides individuals with a way to express their feelings, share their hopes and aspirations, celebrate and remember their achievements. Communication is the basis for individuals and groups to apprehend their organization, what it is and what it means (Hilgerman, 1998).

The importance of communication in institutional performance can be achieved by having a central place in management functions and that managers spend 90 percent of their working days in communication with managers using different communication functions such as notification, command function guidance, impact, persuasion, and suggested functions, as well as integrated functionality (Massey, 2001). Effective communication refers to the ability of communication and ideas to the other party can be easily understood and accepted in a way that is the key to organizational excellence. Organizational excellence comes from the professionalism of people with similar visions. Without effective communication, there is no doubt no progress (Madlock, 2006). Organizations will certainly fail if there is too little communication, too much communication or ineffective communication.

Job satisfaction is a group of positive or negative feelings and emotions, which employees participate in the work. Job satisfaction is an effective attitude, the relative like or dislikes feeling. For example, a satisfied employee can say "I like to do various tasks." Job satisfaction can be regarded as a whole attitude, or can be applied to a single job if only as a whole attitude, however, many managers do not see some key hidden expectations because they get the overall satisfaction of employees (Berger, 2008). 
Therefore, the job satisfaction research is often focused on the parts that are considered very important because of these four tendencies and employees in some way performance. Work satisfaction is important when it comes to cooperation and teamwork, people will find more satisfaction, they are leaving the growth and contribution, so it can be a measure of the workers as a whole, and real-time conditions of work. Job satisfaction is the concept of job satisfaction that communicates climate and manages communication style and it has increasingly become the focus of a wide variety of research (Lok \& Crawford, 2001).

Communication, within organization, plays a very important role. Supportive managerial communication style impacts upon teacher job satisfaction and direct free and open sharing of facts resulting in the smoothness of the process as well as the higher motivation, therefore it is essential to find out the extent up to which effective communication is critical for the effective implementation of quality assurance initiatives in order to attain quality in higher education in Pakistan. The present study is an effort to discover the impact of managerial communication styles on teachers' job satisfaction at Public Sector Universities in Islamabad. It is very important to reveal the dimensions of job satisfaction of teachers in the context of higher education in Pakistan because if they do not do so, the progress and progress of higher education and the society as a whole will become a problem and the survival of the system will be difficult. In this regard, this study will be a valuable contribution to the literature on job satisfaction in higher education and will fill gaps in empirical literature. It will help you to make some personal decision on how you would plan to practice being a leader on the job.

\subsection{Objectives of the Study}

Following were the objects of the study:

1. To find out the existing managerial communication style in public sector universities.

2. To assess the relationship between managerial communication style and teacher's job satisfaction in public sector universities. 


\subsection{Research Questions}

The study answers the following research questions:

1. What are the existing managerial communication styles in public sector universities?

2. What is the impact of managerial communication style on teacher's job satisfaction in public sector universities?

\subsection{Research Design}

The study was based on survey design for collecting and analyzing the data. Quantitative approach was applied for the collection and interpretation of data.

\section{Literature Review}

Mangers plays an important part in the attainment and efficiency of the organization, which is responsible for planning, organizing, supervising, motivating, leading and evaluating the process and the people involved in them. They play the role of diver in the organization, but each character depends on manager's communication (managerial communication skills and styles) that affect the fate of the organization's employees (Emery \& Barker, 2007). Situational factors have been shown to affect job satisfaction. In this method, job satisfaction comes from the nature of the work or work environment. The contextual factor related to job satisfaction is the work level. As higher-level positions are usually more complex and require a higher diversity of skills, they generally perform better and receive better treatment (Akehurst, Comeche \& Galindo, 2009).

Management in all corporate and human organizational activities is simply a behavior that allows people to attain the anticipated goals and objectives together. Management includes planning, organization, staffing, leadership, or guidance which facilitates and controls or multiplies the organization or strives to achieve its goals. Management is a very significant part of the organization, and managers are people who work with others to achieve organizational goals through others. There are some basic features that can be implemented in all types of organizations. In all types of organizations, managers have certain functions to perform in order to generate profits, public and private sector products or 
services; these functions are inherent in manager positions. These functions include plan, organize, command and control (Bass, 1990).

The management functions are completely dependent on communication. This is the communication that makes them in motion, without communication, they are purely abstract. For these main reasons, communication is at the core of the overall management process: the manager can perform the management functions of translation, organization, staffing, direction and control through communication. Information is a prerequisite for decision-making, so the effectiveness of the decision depends on the quality and quantity of the information received. An employer cannot perform his duties effectively unless he or she knows what he is expected to do and how to perform the task in a better way when the task is completed (Niehoff, Enz \& Grover, 1990).

Communicator style is widely considered to mean a way of verbal and nonverbal interaction to show how it should be taken, interpreted, filtered or understood literally. The definition of communication style is dominated by nine independent variables, open, dramatic, relaxed, controversial, animated, friendly, attention and leave the impression. The dependent variable is the communicator image, which represents the evaluation of the communication method. For example, I am a good communicator. Managers in any organization communicate with others to achieve their goals, based on their managerial role. To achieve goals, managers often use different communication functions, including notification, order and teaching, influence, persuasion, advice, integration and maintenance (Roberts \& Bucksey, 2007). It is important to identify the communication style, because the communication style is the personal representative, and the recognition of the personal communication style enables to understand the personal background and his way of thinking and perceive the social reality (Yukl, 2005).

The communication style observed by Norton (1983) is a complex concept, including two dependent views. In the first aspect, the communication style is considered to be the function of forming the content; he thinks that the communication style is affected by the 
system, the context and the time. There are many communication style constructs, and there are different models for conceptualizing the possible communication styles between people. One of the comprehensive models in this regard is Norton's eleven communicator style constructs:

I. Dominant: Dominant communicators are related with significant communicators. The communication style can be considered to reduce the communication behavior of other controls in the communication event.

II. Dramatic: Dramatic communicators are involved in the content of communication content and exhibit high-energy communication behavior. They tend to use metaphors, manipulations, and other devices in communication.

III.Animated: Animation communicators use gestures, vocal emphasis, body movement and posture, so that the content of communication is more colorful.

IV. Open Style: An open communication style person expose his or her real thoughts and feelings, beliefs and opinions in a communicative situation.

V. Precise: Precise communication style is related to argumentation. Controversial communicator style puts a strong stance on controversial issues and is difficult to stop until the problem is resolved.

VI. Contentious: The contentious style relates to argumentation. This style of person in a controversial issue to promote a strong position, it is difficult to stop until it cannot be resolved.

VII. Relaxed: This style of person is a calm, comfortable, relatively no anxiety and tension in the case of communication with people.

VIII. Friendly: This means of communication refers to certain communication behaviors, such as lack of hostility and deep intimacy.

IX.Attentive: This style reflects the sensitivity of social communication. Careful style is demonstrated through nonverbal behaviors such as smile, eye contact, nodding, 
sympathy or good listening.

X. Impression Leaving: This style has something to do with the impressions of the people who communicate with them.

XI. Communicator Image: It refers to the way a person identifies about his or her own communication style.

A long-term topic of interest to HR and operations managers is job satisfaction. Job satisfaction is the perception of a group of favorable or unfavorable employees who observe their work. Job Satisfaction refers to personal attitudes and feelings towards different aspects of his or her work. Job satisfaction refers to the positive emotional orientation of an individual to their current job role (Spector, 1997). It can be explained as a combination of mentalities. Psychological and environmental conditions, leading a person to truthfully say that I am satisfied with my work (Wicker, 2011).

Previously, money was considered to be the only incentive for the job satisfaction, and then later on, people thought that incentives include working conditions, security and possible democratic supervisory style (interpersonal relationships). More recently, the content of motivation is considered to be a higher level of needs or motivations for the satisfaction of employees, such as respect and selffulfillment, responsibility, recognition, achievement, progress, growth and personal development (Alderfer, 1969).

Maslow (1954) identified five levels in his need hierarchy. First level includes Physiological Needs which are the fundamental biological necessities of the human organism (hunger, thrust, sleep, and air), Secondary security needs roughly equivalent to the security requirements of the year plan, the union medical insurance staff rescue plan and pension. Third level need is a social attribute, belonging to intermediate needs, belonging to the needs of the loose correspondence and affiliation (protection, formal and informal workgroup or teams etc.). Fourth level needs are Esteem Needs; achievement and status can be considered part of this level such as titles, status symbols, promotions, banquets achievements etc., and the fifth level is of Self-Actualization which refers to the person motivation to transform perception of self into reality (maximum 
achievement and development of one potential.

Herzberg (1974) extended Maslow's work and developed a concrete content theory. He conducted a widely reported incentive study of approximately 200 companies employed by accountants and engineers. He used critical event methods to obtain analytical data. Herzberg concluded that job satisfaction is associated to job content and that job dissatisfaction is related to the work environment. Herzberg marked the satisfiers as Motivators and called the dissatisfiers as Hygiene Factors.

In an educational environment factors that lead to a high sense of work (motivating factors) and feelings of low teacher work are mutually exclusive. Achievement, recognition and responsibility are the dominant factors in teachers' job satisfaction. Interpersonal relationships (supervisors, technology, school policy and administration) are the main factors of dissatisfaction with teachers' work, promotion, and work itself seems to be a source of satisfaction and dissatisfaction.

\subsection{Population of Study}

\section{Research Methodology}

All teachers and heads of social sciences department of public sector universities of Islamabad constituted the population of the study.

\subsection{Sample and Sampling Technique}

In order to select representative sample from the target population, 40 teachers and 10 heads were selected from one public sector university of Islamabad by using convenient sampling technique.

\subsection{Instruments}

Keeping in view the nature and need of the study following two instruments were used;

\subsubsection{Communicator Style Measurement Scale}

The communicator style measurement scale was based on the CSM-51 (Norton, 1983). A five step Likert scale was used which were 'Never, Rare, Often, Sometimes and Always'. 


\subsubsection{The Minnesota Satisfaction Questionnaire}

The Minnesota Satisfaction Questionnaire (1977) was used to measure employee satisfaction with the job. MSQ provides more specific information about the work of individuals in receiving rewards, rather than using more general job satisfaction measurements.

\section{Data Analysis}

For data analysis frequencies, mean and Pearson correlation were applied through SPSS.

Table 1 Mean score of Communication Styles

\begin{tabular}{lll}
\hline Communication Styles & Mean & Remarks \\
\hline Friendly & 2.3 & Rare \\
Impression Leaving & 2.5 & Often \\
Relax & 2.7 & Often \\
Argumentative & 3.5 & Sometimes \\
Attentive & 2.6 & Often \\
Precise & 2.6 & Often \\
Expressive & 2.5 & Often \\
Dramatic & 2.5 & Often \\
Open & 2.4 & Rare \\
Dominant & 4.2 & Sometimes \\
\hline
\end{tabular}

Table No. 1 shows the mean scores of all the ten factors of communication styles. Impression leaving style had 2.5 mean, Relax style of communication mean is 2.7, and mean of Argumentative communication style is 3.5. Attentive style exhibit 2.6 mean score and Precise style had mean score 2.6. Expressive management communication style had 2.5 mean score, Dramatic style had 2.5 and Open style of communication means score is 2.4. Result shows that Dominant style had the highest mean score that was 4.2 , whereas Friendly style had the lowest mean score that was 2.3.

Table 2 Relationship between communication styles and Job satisfaction

Variables

Friendly
Job Satisfaction

$.456 *$ 


$\begin{array}{lc}\text { Impression Leaving } & -.342^{*} \\ \text { Relax } & .389^{*} \\ \text { Argumentative } & -.472^{* *} \\ \text { Attentive } & .287^{*} \\ \text { Precise } & -.349^{*} \\ \text { Expressive } & .437 * \\ \text { Dramatic } & .410^{*} \\ \text { Open } & .436^{*} \\ \text { Dominant } & -.390^{* *}\end{array}$

Table No. 2 shows a correlation between communication styles and teachers job satisfaction. There is a significant positive correlation exist between job satisfaction and Friendly, Relax, Attentive, Expressive, Dramatic and Open communication styles. A significant negative correlation exist between job satisfaction and Impression leaving, Argumentative, Precise and Dominant communication styles.

\section{Findings}

1. Findings revealed that Dominant style had the highest mean score whereas Friendly style had the lowest mean score.

2. A significant positive correlation exist between job satisfaction and Friendly, Relax, Attentive, Expressive, Dramatic and Open communication styles.

3. A significant negative correlation exist between job satisfaction and Impression leaving, Argumentative, Precise and Dominant communication styles.

\section{Discussion and Conclusion}

Findings of this study revealed that dominant managerial communication style had the highest mean, whereas friendly managerial communication style had the lowest mean score. Findings of the study were in line with the study conducted by Bradley and Baird (1977) in which several approaches to management varying dimensions of the communication styles of managers were investigated, results revealed that democratic style was characterized by relaxation, attentiveness, animation and friendliness styles and 
were practiced more in organization as compared to other communication styles.

Findings of the present study propose that there is a significant positive correlation exist between job satisfaction and friendly, relax, attentive, expressive, dramatic and open managerial communication styles. Studies reported that job satisfaction is influenced by different factors including communication satisfaction and managers communication style (Hilgerman, 1998).

Among the determinants of job satisfaction, management style is measured as a significant interpreter and has a key role. Studies in many countries showed that management style is positively correlated with job satisfaction (Vance \& Larson, 2002; Berson \& Linton, 2005; Mosadeghrad \& Yarmohammadian, 2006). Sellgren (2006) reports that the manager's style is crucial to subordinates' acceptance of change and motivation to fulfill their stated vision and goals, as well as to high quality care.

\section{Recommendations}

1. By keeping in mind the findings of the study it is suggested that teacher's job satisfaction can be improved by further providing specific managerial styles training to the heads and managers on regular basis by taking help of national and international trainers. Online training sessions may also be organized.

2. Communication is a two way process it is suggested that employees should be trained so that they are able to familiarize themselves with the communication styles used by their heads and managers.

3. Workshops and seminars about communication styles may be conducted in organization for information purpose to employees.

4. The present study only focused on teachers of public sector universities, it is suggested that further researchers may conduct comparative studies between public sector and private sector university teachers. 


\section{References}

Akehurst, G., Comeche, J., \& Galindo, M. (2009). Job satisfaction and commitment in the entrepreneurial SME. Small Business Economics, 32(3), 277-289. http://dx.doi.org/10.1007/s11187-0089116-Z

Alderfer, C. P. (1969). An empirical test of a new theory of human needs. Organizational Behavior \& Human Performance, 4(2), 142175.http://dx.doi.org/10.1016/0030-5073(69)90004-X

Bass, B. (1990). Bass \& Stogdill's Handbook of Leadership: Theory, Research and Managerial Applications ( $3^{\text {rd }}$ ed.). New York: Free Press.

Berger, B. K. (2008). Getting communications on senior management's agenda. In P. Williams (Ed.), Employee communication: The comprehensive manual for those who communicate with today's employee (pp. 97-114). Chicago: Ragan Communications.

Berson, Y. \& Linton, J. D. (2005). An examination of the leaderships between leadership style, quality and employee satisfaction in $\mathrm{R} \& \mathrm{D}$ versus administrative environments, $R \& D$ Management, 35 , 51-60.

Bradley, P. H. \& Baird Jr., J. E. (1977). Management and Communicator Style: A Correlational Analysis. Communication Studies, 28, 194-203.

Emery, C. R., \& Barker, K. J. (2007). The effect of transactional and transformational leadership styles on the organizational commitment and job satisfaction of customer contact personal. Journal of Organizational Culture, Communication \& Conflict, 11(1), 77-90.

Herzberg, F. (1974). Work and the nature of man. London: Crosby Lockwood Staples.

Hilgerman, R. (1998). Communication satisfaction, goal setting, job satisfaction, concretive control and effectiveness in self-managed teams. Dissertation Abstracts International, 59, 1661-1669. 
Lok, P., \& Crawford, J. (2001). Antecedents of organizational commitment and the mediating role of job satisfaction. Journal of Managerial Psychology, 16, $594-613$.

Madlock, P. E. (2006). Do differences in displays on nonverbal immediacy and communicator competence between male and female supervisors affect subordinates, job satisfaction? Ohio Communication Journal, 44, 61-78.

Maslow, A. H. (1954). Motivation and Personality. New York: Harper and Row.

Massey, J. E. (2001). Managing Organizational Legitimacy: Communications Strategies for Organizations in Crisis. Journal of Business Communication, 38, 153-183.

Mosadeghrad, A. M. \& Yarmohammadian, M. H. (2006). A study of relationship between manager's leadership and employee's job satisfaction, Leadership in health service, 19(2), 11-18.

Niehoff, B. P., Enz, C. A, \& Grover, R. A. (1990). The impact of topmanagement actions on employee attitudes and perceptions. Group \& Organization Studies, 15(3), 337-352.

Norton, R. (1983). Communicator Style. Beverly Hills, Calif.: Sage.

Roberts, L. \& Bucksey, S. J. (2007). Communicating with patients: What happens in practice? Physical Therapy, 87, 586-594. doi: $10.2522 / \mathrm{ptj} .20060077$

Sellgren, S. EkVallg \& Tomson, G. (2006). Leadership styles in nursing management: preferred and perceived. Nursing Management, 14(5), 345-355.

Spector, P. (1997). Job satisfaction: Application, assessment, cause and consequences. Thousand Oaks, CA: Sage.

Vance, C., \& Larson, E. (2002). Leadership research in business and health care, J. nurse scholash, 34(2), 165-71.

Wicker, E. (2011). Job Satisfaction: Fact or Fiction. Author House.

Yukl, G. A. (2005). Leadership in Organizations (6 ${ }^{\text {th }}$ ed.). Upper Saddle River, NJ: Prentice Hall.

Zalabak, P. (2002). Fundamentals of Organizational Communication. ( $5^{\text {th }}$ ed.) Boston: Houghton. 